\title{
Assessing climatic and intrinsic factors that drive arthropod diversity in bird nests
}

\section{Evaluando los factores climáticos e intrínsecos que explican la diversidad de artrópodos dentro de nidos de aves}

\section{Gastón 0. Carvallo*, Manuel López-Aliste, Mercedes Lizama, Natali Zamora \& Giselle Muschett}

Instituto de Biología, Facultad de Ciencias, Pontificia Universidad Católica de Valparaíso, Campus Curauma, Avenida Universidad 330, Valparaíso, Chile.

*E-mail: gaston.carvallo@pucv.cl

\begin{abstract}
Bird nests are specialized structures that act as microrefuge and a source of food for arthropods. Nest arthropod richness and composition may vary according to the nest builder, geographical location and nest size. Because information on nest arthropods is scarce, there are even fewer studies on the drivers of nest arthropod diversity. We characterized arthropod diversity in cup- and dome-shaped nests along a $130 \mathrm{~km}$ latitudinal gradient in the mediterranean-type region of Central Chile and, we assessed whether nest dimensions and climatic factors explain richness (alpha-diversity). Then, we evaluated whether climatic differences between sites explain arthropod nest composition (beta-diversity). All collected nests hosted at least one arthropod specimen. We identified 43 taxonomic entities ( 4.2 entities per nest \pm 0.5 , mean $\pm S E, n=27$ nests) belonging to 18 orders and five classes: Arachnida, Diplopoda, Entognatha, Insecta and Malacostraca. We observed differences in nest arthropod richness and composition related to sites but not bird species. Larger nests supported greater arthropod richness. Furthermore, we observed that climatic differences explain the variation in arthropod composition between sites. Nests in the northern region (drier and warmer) mainly hosted Hemipterans and Hymenopterans. Contrary, nests in the southern region (humid and colder) hosted species of Collembola, Dermaptera, and Diplopoda. Positive relationship between nests surface area with arthropod richness suggests us that larger nests may keep more resources. Our study sheds light on a crucial interaction which may have potential consequences for insect assemblage composition and bird reproductive biology.
\end{abstract}

Keywords: biological interactions, invertebrates, mediterranean-type ecosystem, taxonomic composition.

\section{RESUMEN}

Los nidos de aves actúan como microrefugios para artrópodos con variación en su diversidad, mediada entre otros factores, por las especies de aves constructoras, la ubicación y el tamaño de los nidos. En este estudio caracterizamos la diversidad de artrópodos que viven en nidos con forma de copa y domo en Chile Central evaluando si las dimensiones del nido y los factores climáticos explican su riqueza (diversidad alfa) y si las diferencias climáticas entre sitios explican diferencias en composición (diversidad beta). Identificamos un total de 43 entidades taxonómicas en los nidos ( 4,2 entidades por nido $\pm 0,5$, media $\pm E S, n=27$ nidos) pertenecientes a 18 órdenes y cinco clases. La riqueza y composición de artrópodos de nidos presentó diferencias entre sitios, pero no entre aves. Los nidos con mayor superficie albergaron mayor riqueza. Las diferencias climáticas entre sitios explicaron la variación en composición: la zona septentrional (condiciones secas y cálidas) presentó dominancia de Hemípteros e Himenópteros. En los nidos de la zona sur (condiciones húmedas y frías) dominaron especies de los 
órdenes Collembola, Dermáptera y Diplopoda. La relación positiva entre la superficie de los nidos con la riqueza de artrópodos sugiere que nidos de mayor dimensión dispondrían de más recursos, favoreciendo la diversidad de artrópodos. Nuestro estudio contribuye a esclarecer una interacción clave que impacta los ensambles de insectos y la biología reproductiva de las aves.

Palabras clave: composición taxonómica, ecosistema mediterráneo, interacciones biológicas, invertebrados.

\section{INTRODUCTION}

Bird nests are specialized structures whose primary function is host eggs and fledglings generating favorable conditions and acting as a refuge against antagonistic interactors (Deeming \& Mainwaring 2015). Nests can become micro-environments with available resources suitable to invertebrates in where they find shelter, stable microclimatic conditions and food (Tajovský et al. 2001; Di lorio \& Turienzo 2009; López-Rull \& García 2015; Miquel et al. 2015). In bird nests, invertebrates are mainly arthropods that act as ectoparasites of fledglings reducing their survival (Mainwaring et al. 2014; López-Rull \& García 2015). Arthropods in bird nests occur beyond of bird reproductive season playing other ecological roles within, such as decomposers, since they use resources available in nests such as faeces, feathers or plants (Aramburú et al. 2009; Di lorio \& Turienzo 2009; Splinski \& Tomaszewska 2010).

Several factors control the composition and abundance of arthropods within bird nests. Among these factors, bird species (López-Rull \& García 2015; Fecchio et al. 2017), nest location (López-Rull \& García 2015), nest material/ architecture (Mainwaring et al. 2014; Boyes \& Lewis 2019), and the presence of other invertebrates (Lambrechts et al. 2008) are mentioned as drivers of arthropod diversity within nests. When nest arthropods are studied at a community level, spatial proximity among nests and phylogenetic relatedness of birds that build nests arise as the leading candidates to determine the similarity of arthropod composition residing within (Poulin et al. 2011). However, recent studies show a null effect of bird species and site on community structuration of some specific group of arthropods (e.g., moths, Boyes \& Lewis 2019). This situation could be attributable to the limited dispersal capacity of arthropods at both local (Lundqvist 1988; Rataud et al. 2019) and biogeographical scales (Poulin 2011; Fecchio et al. 2017) suggesting that arthropods transfer between nests via direct contact with infected birds (López-Rull \& García 2015). Under this scenario, the close spatial proximity of nests may increase the similarity of arthropod assemblages reducing beta-diversity between nests. In addition, a higher phylogenetic relatedness of birds can determine the similarity of arthropods hosted in nests because closely related birds share nest structure and materials (Winkler and Sheldon 1993). In this instance, beta-diversity of nest arthropods may increase as bird assemblage are more diverse and bird species are less evolutionary related.

Although arthropod diversity within bird nests has ecological importance, for instance, as decomposers (which break down waste products; Aramburú et al. 2009; Boyes \& Lewis 2019) and predators (which reduce densities of avian parasites; Woodroffe 1953), a comprehensive knowledge of these invertebrate groups is far from being clear. Most studies of bird nest arthropods have focused on their taxonomic description (Di lorio \& Turienzo 2009, 2016) leaving aside other biodiversity components of assemblages such as functional and phylogenetic diversity. For example, a review that included nest insects from Neotropical region of South America found 123 species pertaining to 96 genera of 13 orders ( $\mathrm{Di}$ lorio \& Turienzo 2009) identifying clades as detritivorous of nest material such as Poduromorpha (Collembola), Muscoidea (Diptera), Tenebrionidae (Coleoptera) and Scarabaeidae (Coleoptera) (Aramburú et al. 2009; Di lorio \& Turienzo 2009). In the most comprehensive study at the global scale, Hicks (1953) described 18 orders of arthropods in bird nests. Less common are studies that have boarded trophic interactions among nest arthropods. For instance, predation of arthropods within the bird nests is exerted mainly by spiders (Judd 1962; Aramburú et al. 2009). Since studies of alpha- and beta-diversity of nest arthropods are virtually unknown (but see Boyes \& Lewis 2019), in this study study we aimed to characterize potential drivers of arthropod composition of cup- and domed-shaped nests that occur in a coastal strip of a mediterranean-type ecosystem in Central Chile. This region is highly endangered and considered a biodiversity hotspot (Myers et al. 2000; Armesto et al. 2010; Alaniz et al. 2016) which makes having basic ecological information of biotic components of these environments more urgent. We differentiated intrinsic variables that potentially affect arthropod diversity within bird nests (e.g. nest dimensions, bird species) and extrinsic variables such as climatic conditions. We based our study 
on two common nest architectures: cup-shaped and domedshaped nests. Specifically, we assessed taxonomical richness and composition of nest arthropods among sites and bird species.

\section{MATERIALS AND METHODS}

\section{STUDY SITES AND NEST SAMPLING}

We centered our study in nine sites along a latitudinal strip of $131 \mathrm{~km}$ (Fig. 1). This region corresponds to a mediterraneantype ecosystem (Esler et al. 2018) with rainy and colder temperatures in winter (May - September) and drier and warmer conditions in summer (October - April) (Luebert $\&$ Pliscoff 2017). The studied region encompasses shrub vegetation dominated by Peumus boldus (Monimiaceae) and Schinus latifolius (Anacardiaceae) in their northern portion, and sclerophyllous forest in the southern portion dominated by Cryptocarya alba (Lauraceae) and Lithraea caustica (Anacardiaceae) (Luebert \& Pliscoff 2017).

To determine nest builders (birds), we used different methods. First, we identified birds through direct observation in the field when nests were active during the reproductive season (September 2015 to January 2016). These observations revealed the identity of birds that flew to the nests to feed chicks, and we georeferenced these nests for their subsequent collection. We identified 12 nests using this approach (Appendix S1). Second, we used trail camera traps (Browning Strike Force, UT, USA) installed in front of nests for 30 days, and alternated cameras among nests between October and December 2015. This approach was carried out in three sites (Pichidangui, Los Molles, and Acantilados de Federico Santa María). Using four trail cameras, we identified four additional nest builders.

The third approach used biological remains of bird origin within nests, which were identified based on their DNA sequence. We extracted DNA from faeces, feathers, or talons available within nests. These samples were collected during nest extraction. The DNA of samples was isolated using the DNAEasy Blood and Tissue Kit (Qiagen Inc.) according to the manufacturer's protocol. We amplified the mitochondrial cytochrome $c$ oxidase 1 (COI) gene employed as a standard "DNA barcode" for identifying animal species (Hebert et al. 2003) using two "vertebrates (non-fish)" primer cocktails: VF and VR (Ivanova et al., 2007; Appendix S2). Obtained sequences were compared, employing the "Barcode of Life Data" identification system (BOLD, http://www.boldsystems. org; Ratnasingham \& Hebert 2007). This method accepts sequences of the $\mathrm{COI}$ gene and reports species-level identification whenever possible and assigns a percentage of the match to sampled sequences. We used this method on an additional 11 nests (Appendix S1).

We collected abandoned nests between May to June 2016, corresponding to the bird post-reproductive season in this region. For each site, the collection was done on a previously outlined track of $4,000 \mathrm{~m}$ that crossed patches of vegetation determined on satellite images available in Google Earth. We walked the traced track and collected all observed cup- and dome-shaped nests (up to a limit of $3 \mathrm{~m}$ above the ground). Each collected nest was georeferenced. We placed a fabric sheet under each nest as they were gently removed to collect any nest invertebrate, which were deposited in vials. Then, we wrapped the nests using plastic film and placed it in paper bags. We carried the nests to the laboratory where they were placed in a dry oven for 48 hours at $40{ }^{\circ} \mathrm{C}$ and weighed. Once nests were dried, we carried out an exhaustive search of any animals amid nests parts. All collected nest invertebrates (both in the field and laboratory) were identified to the most specific taxonomic level possible using the following taxonomic keys: Peña (2006), Saiz et al. (1989) and Solervicens (2014) for insects; Aguilera \& Casanueva (2005) and Grismado et al. (2014) for Araneae. Since we were unable to identify the majority of specimens to species level, we based our analyses on taxonomic entities rather than species. Based on the collected information, we generated a quantitative nest-taxonomic entities matrix.

\section{TAXONOMIC DIVERSITY ANALYSES}

We performed rarefaction analyses (Colwell et al. 2012) to assess whether the number of nests sampled was suitable to characterize nest arthropod richness. Also, we performed rarefaction analyses differentiating between bird species (only those species for which least three nests were collected: Phytotoma rara, Pseudasthenes humicola and Turdus falcklandii) and sites (only sites for which least three nests were collected: El Carmen, El Mauco, La Canela, Los Molles, Los Pinos, and Pichidangui; Fig. 1). Additionally, based on rarefaction analyses described above, we compared nest arthropod richness among bird species and sites. Richness comparison between species was made for accumulation curves based on 15 nests $\left(\right.$ RAR $\left._{15}\right)$ after an extrapolation procedure (Colwell et al. 2012). Comparison between sites was made based on ten nests $\left(\mathrm{RAR}_{10}\right)$ after extrapolation. We considered richness was different between species and sites when $95 \%$ confidence intervals did not overlap. Rarefaction analyses were performed using iNext package (Hsieh et al. 2016) for R.

The compositional differences between assemblages of each nest was estimated using the Bray-Curtis dissimilarity index which ranges from 0 (the same composition of the 
compared samples or the lowest taxonomic beta-diversity) to 1 (complete dissimilarity between the compared samples or the highest taxonomic beta-diversity). We assessed whether Bray-Curtis index varied between bird species or localities using ANOSIM (analysis of similitude; Clarke 1993) and comparing $95 \%$ confidence intervals represented by ellipses ordered in a multivariate space obtained by multidimensional scaling. Groups were considered significantly different when $95 \%$ confidence intervals of the ellipses did not overlap.
Additionally, we assessed climatic variables (annual mean temperature, and the annual mean precipitation) contribute to explain arthropod nest richness. We performed generalized linear models (GLM) between arthropod richness and the cited variables including all nests. We obtained climatic variables from WorldClim (Hijmans et al. 2005) extracting values for each georeferenced nest. Also, since the area is the main driver of diversity in ecological systems (Harte et al. 2009), we included the nest surface area in our models.

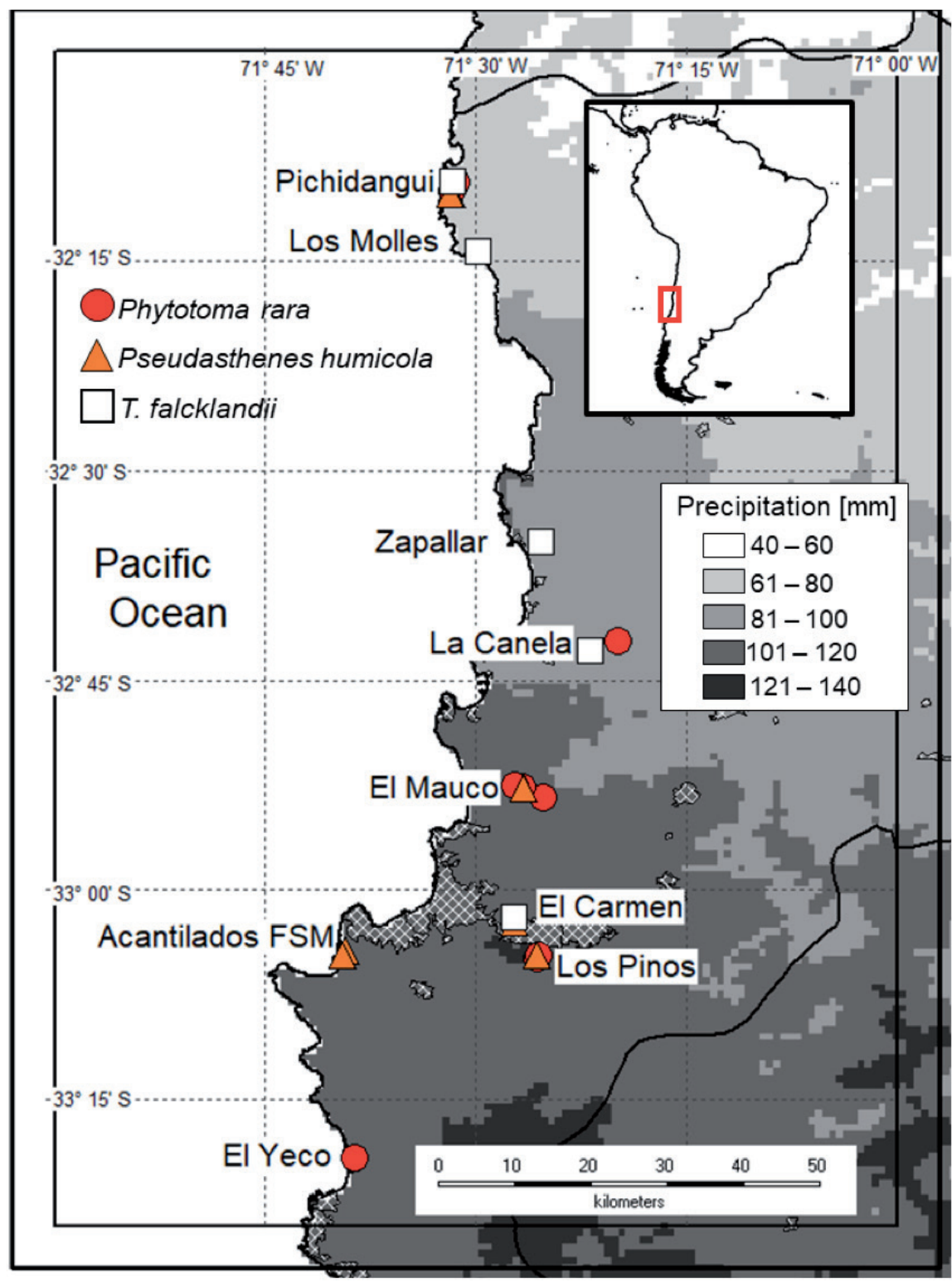

FIGURE 1. Distribution of bird nests studied in nine localities along a latitudinal gradient in Central Chile. Symbols depict bird species, although, for the sake of clarity, we omitted three bird species: B. magellanicus, Patagioenas araucana, and Troglodytes aedon (see Table 1). Cross-hatched polygons depict urban areas. / Distribución de los nidos de aves estudiados en nueve localidades a lo largo de un gradiente latitudinal en Chile Central. Los símbolos representan a las especies de aves, aunque para la claridad de la figura, se omiteron tres especies de ave: B. magellanicus, Patagioenas araucana, y Troglodytes aedon (ver Tabla 1). Áreas achuradas representan zonas urbanas. 
Nest surface area was estimated following Heenan and Seymour (2011), based on nest diameter and height using the equation for half of a prolate spheroid. Also, we included nest mass to assess their contribution to arthropod nest richness. Generalized linear models were run using the glm function in R 3.5.3 (R Core Team 2019) with Gaussian response and identity link function. Previous to performing the GLM, we checked whether our data fit assumptions of GLM (normal distribution of residuals and homocedasticy of variance) based on inspection of residuals vs. fitted values, and normal distribution of residuals. Model selection was done based on Akaike information criteria. In addition, we assessed the effect of each studied variable with arthropod richness using linear regression.

Finally, we assessed whether differences of species in composition between nests (ecological distance) is related to the geographical, climatic and phylogenetic distance of birds using Mantel test (Mantel 1967) with a Pearson correlation (999 iterations; Rezende et al. 2007). Distances were estimated using dissimilarity of Bray-Curtis index. The ecological distance was based on the arthropod-nest matrix. Climatic distances were estimated independently for annual mean precipitation and temperature. To obtain a phylogenetic distance matrix between birds' species we used cophenetic function using picante package (Kembel et al. 2010) for R. Previously, we assembled a phylogenetic tree using BirdTree (Jetz et al. 2012) a tool that provides a calibrated phylogenetic reconstruction based on a subset of species.

\section{RESULTS}

\section{NeST BUILDERS AND NEST SIZE}

We collected a total of 27 nests from six different bird species (Appendix S1). Species included one owl (Strigiformes), one pigeon (Columbiformes) and four species of passerines. The passerines made up the majority of nests collected $(n=25$ nests). Among passerines, there were four nests attributable to Dusky-tailed canastero Pseudasthenes humicola (Furnaridae), a small endemic Chilean species, which builds conspicuous dome-shaped nests unique in the study region (Table 1 , Appendix S1). Among nests, surface area averaged $1,164 \mathrm{~cm}^{2}$ \pm 125 (mean \pm SE; range $249-2364 \mathrm{~cm}^{2}$ ), height $151 \mathrm{~mm} \pm$ 13 (range: 60 - $310 \mathrm{~mm}$ ), diameter $171 \mathrm{~mm} \pm 7.7$ (range 90 $230 \mathrm{~mm}$ ) and mass $167 \mathrm{~g} \pm 21$ (range $8-480 \mathrm{~g}$ ). The heavier nests were of $P$. humicola, and the largest surface area was observed in $P$. rara (Table 1).

INSECT DIVERSITY

We identified 43 arthropod entities ( $n=845$ individuals;
Table 1). All nest arthropods were identified at least to order level, $74 \%$ of nest arthropods ( $n=32$ entities) were identified to the family level, and only $28 \%$ ( $n=12$ entities) were identified to genera (Appendix S1). Rarefaction showed that the number of nests sampled was adequate to characterize arthropod richness at the coarse taxonomic level used (Appendix S3). Among sampled nests, we observed a mean richness of 4.2 entities $( \pm 0.5$, SE; range: 1 - 13 per nest) and 31 individuals per nest ( \pm 13 ; range: 1 - 341 per nest). All invertebrates identified belong to phylum Arthropoda, distributed in five classes (Arachnida, Diplopoda, Entognatha, Insecta and Malacostraca; Appendix S1) and 18 orders (Fig. 2). Insecta was the most diverse class comprising 12 orders and 615 individuals, followed by class Arachnida represented by three orders and 142 individuals (Fig. 2). Classes Diplopoda (Spirosptredptida), Entognatha (Collembola) and Malacostraca (Isopoda) were represented by individuals assigned at only one taxonomic entity each (Appendix S1 and Fig. 2).

Our best models indicate that intrinsic factors (nest surface area and mass) explain arthropod richness of nests (Table 2). When nest mass was included as the only variable, this had a low predictive value on arthropod richness (Table 2 ). When variables were independently regressed with arthropod diversity we observed a positive and significant effect of surface area $(\beta=0.003 \pm 0.000 ; t=2.852 ; P=$ 0.009 , Fig. 3) but not with nest mass $(\beta=-0.006 \pm 0.005 ; \mathrm{t}=$ 1.256; $P=0.223$ ). Nest and area and mass were positive and statistically related between them $(\beta=2.57 \pm 0.97 ; t=2.663$; $P=0.014)$. When nest area was analyzed independently by bird species, birds did not show a relationship with arthropod richness ( $P$. rara: $\beta=0.002 \pm 0.001, \mathrm{t}=1.664, \mathrm{P}>0.05 ; P$. humicola $\beta=-0.002 \pm 0.003, \mathrm{t}=0.505, \mathrm{P}>0.05 ;$ T. falcklandii: $\beta=0.002 \pm 0.000, t=5.529, P=0.034)$. A similar pattern was observed with regard to nest mass: we did not observe a relationship between arthropod richness and bird species ( $P$. rara: $\beta=0.002 \pm 0.012, t=0.139, P>0.05 ; P$. humicola $\beta=$ $-0.009 \pm 0.003, t=0.272, P>0.05 ;$ T. falcklandii: $\beta=-0.003 \pm$ $0.004, \mathrm{t}=0.777, \mathrm{P}=0.494$ ).

Generalized linear models showed that extrinsic variables (climatic variables) have the lowest predictive value on arthropod richness (Table 3). Annual mean temperature between sites where nests were sampled averaged $14.7^{\circ} \mathrm{C} \pm 0.2$ (range: $13.2-16.6 \mathrm{C}$ ) although we did not observe a statistical relationship between annual mean temperature and arthropod richness $(\beta=0.216 \pm$ $0.437 ; \mathrm{t}=0.492 ; \mathrm{P}>0.05)$. Annual precipitation averaged $430 \mathrm{~mm} \pm 21$ (range: $264 \mathrm{~mm}-580 \mathrm{~mm}$ ) but did not show a relationship with arthropod richness $(\beta=1.002 \pm 0.633$; $\mathrm{t}=1.584 ; \mathrm{P}>0.05$ ). 


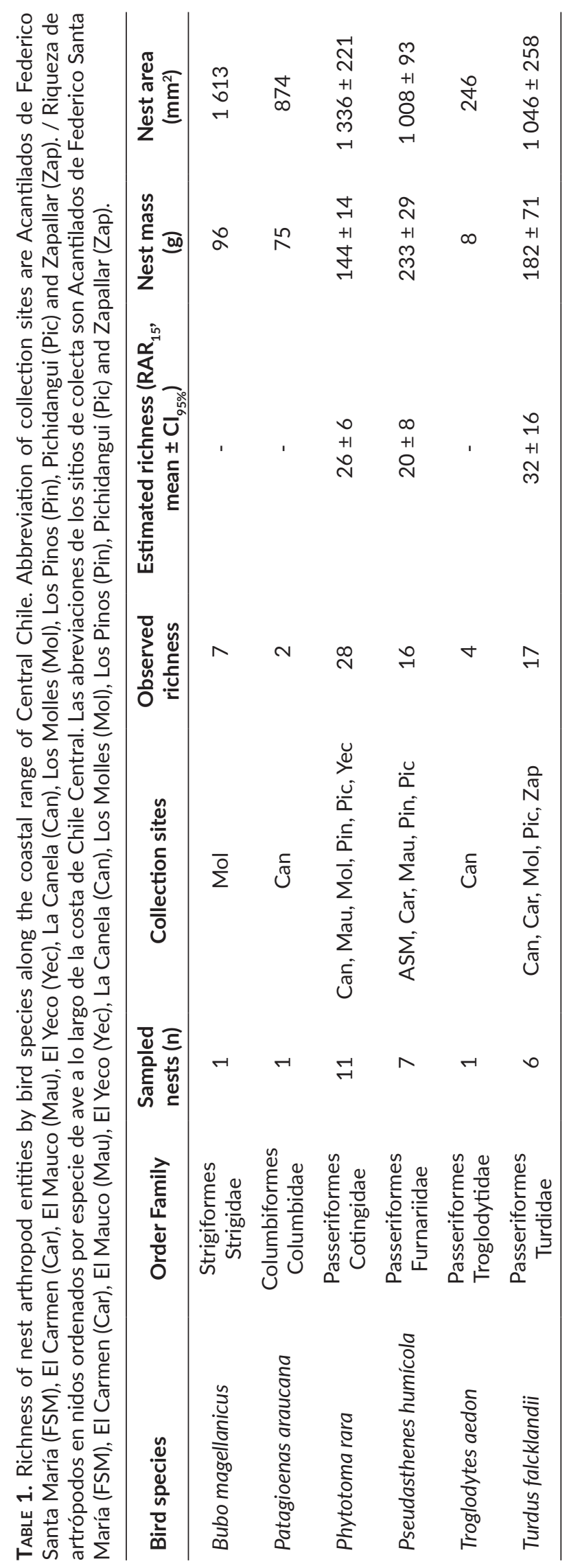




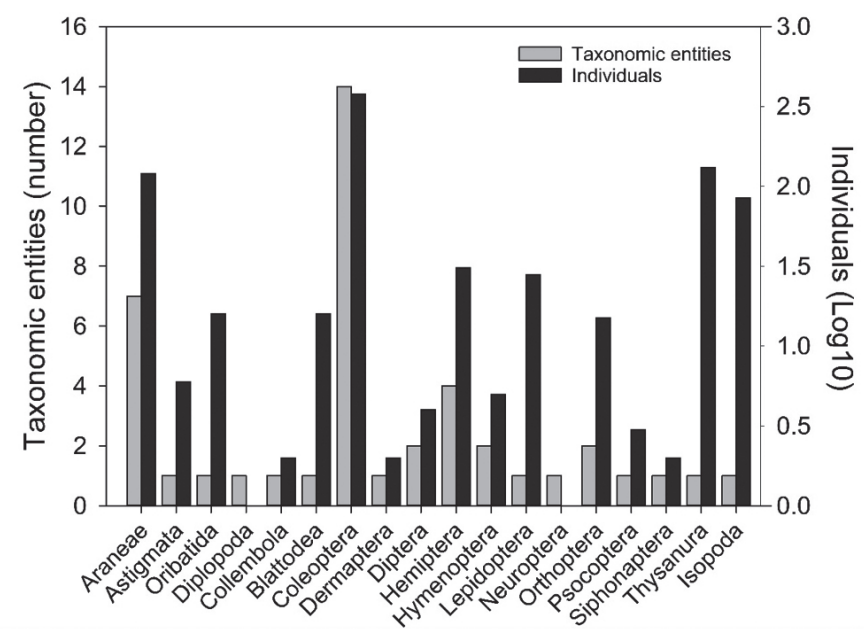

FIGURE 2. Arthropod orders observed within bird nests in Central Chile. We reported the number of taxonomic entities (left axis) and number of individuals within each (right axis). / Órdenes de artrópodos observados dentro de nidos de ave en Chile Central. Reportamos el número de entidades taxonómicas (eje de la izquierda) y el número de individuos dentro de cada orden (eje de la derecha).

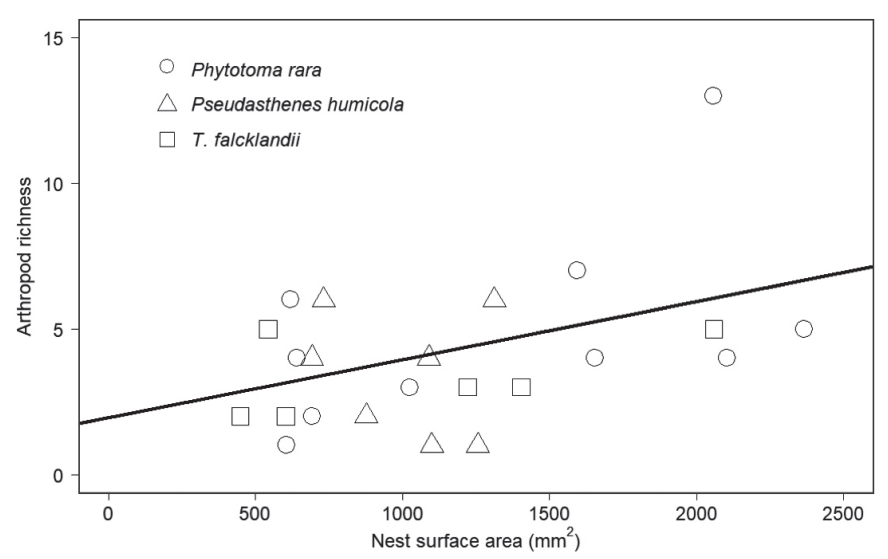

FIGURE 3. Relationship between nest surface area and nest arthropod richness. Line depicts the result of a linear regression including all nests. / Relación entre el área superficial de los nidos y la riqueza de artrópodos de nidos. La línea representa el resultado de una regresión lineal que incluyó a todos los nidos.

TABLE 2. Generalized linear models testing the different variables predicting arthropod richness in bird nests, Central Chile. Models were ordered from the lower to higher AIC values. df: degrees of freedom. Deviance: quality of fit statistics for the models. AIC: Akaike information criteria. $\mathrm{R}^{2}$ : correlation between the fitted and observed values. S: nest surface. M: nest mass. T: annual mean temperature. P: annual precipitation. / Modelos lineares generalizados que evaluaron como diferentes variables impactan la riqueza de artrópodos de nidos de aves en Chile Central. Los modelos fueron ordenados desde los menores a mayores valores de AIC. df: grados de libertad. Deviance: calidad de adecuación estadística de los modelos. AIC: Criterio de información de Akaike. R²: correlación entre los valores adecuados y observados. S: superficie de nidos. M. masa de nidos. T: temperature media annual. P: precipitación anual.

\begin{tabular}{lllcc}
\hline Models & df & AIC & Deviance & $\mathbf{R}^{2}$ \\
\hline $\mathrm{S}+\mathrm{M}$ & 23 & 114 & 159 & 0.27 \\
All variables & 23 & 115 & 159 & 0.22 \\
Nest Surface (S) & 24 & 118 & 159 & 0.19 \\
Nest mass (M) & 25 & 130 & 179 & 0.01 \\
Annual mean temperature (T) & 26 & 133 & 179 & 0.01 \\
Annual precipitation (P) & 26 & 133 & 179 & 0.02 \\
T + P & 26 & 135 & 179 & 0.02 \\
\hline
\end{tabular}

Among bird species, Phytotoma rara nests presented the highest arthropod richness ( $N=28$ arthropod entities) although rarefaction analysis showed there were no statistical differences among $P$. rara, $P$. humicola $(\mathrm{N}=16$ entities) and $T$. falcklandii ( $N=17$ entities) (Table 1; Appendix S3). We did not observe compositional differences of nest arthropods among P. rara, P. humicola and T. falcklandii (ANOSIM R = -0.021; $\mathrm{P}$ $=0.584$; Fig. 4 a) although compositional differences were relatively high values (near to 1 ) and varied between 0.94 (between P. rara and P. humicola) to 0.95 (between P. rara and
T. falcklandii). The ecological distance among nests based on arthropod composition (measured as Bray-Curtis distance) was not related to the evolutionary distance of birds (Mantel $R=0.046 ; P=0.220$ ), which rules out a phylogenetic effect of bird species on nest arthropod composition.

Between sites, arthropod richness varied from two taxonomic entities in Acantilados FSM and Zapallar to 16 taxonomic entities in La Canela (Table 3). The rarefaction analysis showed that there were no statistical differences in arthropod richness between sites (Table 3; Appendix S3). 
Multidimensional scaling showed compositional differences between sites (ANOSIM R =0.260; $\mathrm{P}=0.004$; Fig. 4b). Two pairs of sites showed a higher differentiation in their arthropod composition (Bray-Curtis distance $=0.98$ ): La Canela-El Carmen ( 37 km apart) and Los Molles-El Mauco ( $74 \mathrm{~km}$ apart), while Los Molles-Pichidangui ( 10 km apart) showed the lowest compositional differences (Bray-Curtis distance $=0.82$ ). We observed a positive and statistical relationship between ecological and geographical distances among nests (Fig. 5): as geographical distance increases so does dissimilarity between nests (Mantel $\mathrm{R}=0.219$; $\mathrm{P}=$ 0.002). Both temperature (Mantel $R=0.160, P=0.012$ ) and precipitation (Mantel $\mathrm{R}=0.160 ; \mathrm{P}=0.021$ ) were positively related with compositional differences (Fig. 5).

(a)

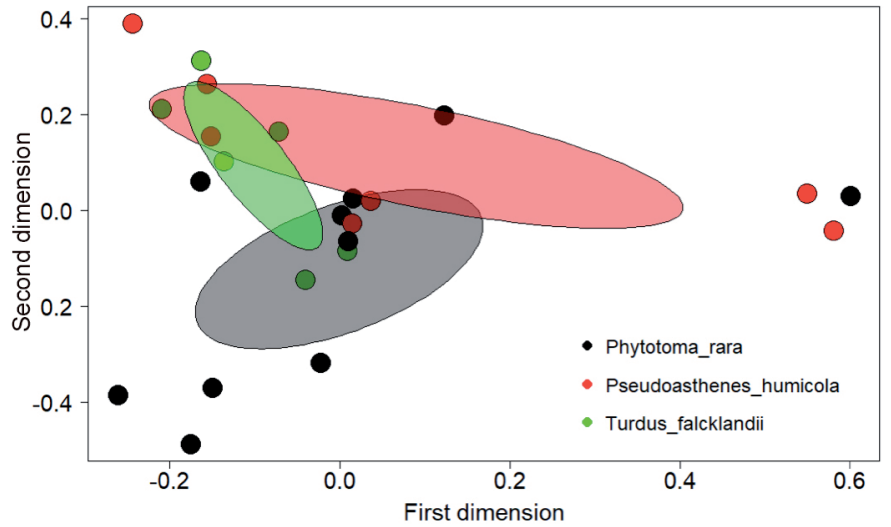

(b)

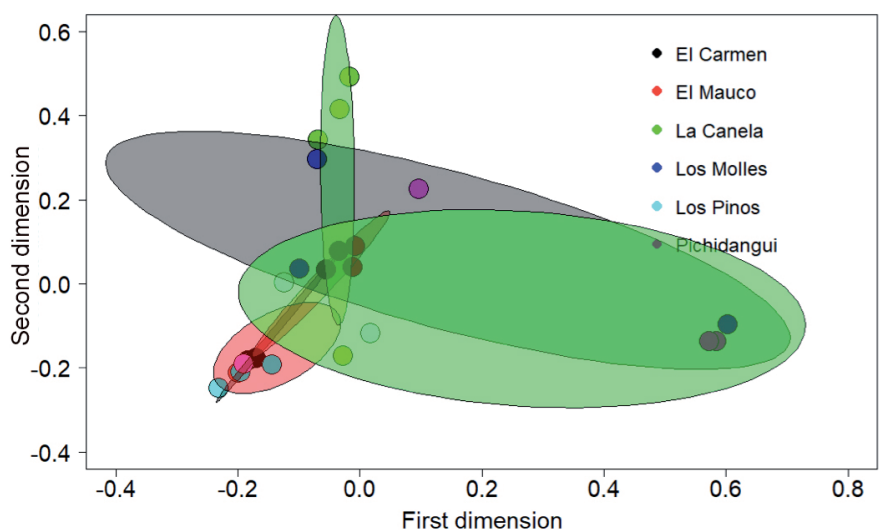

Figure 4. Multidimensional scaling plots to examine compositional differences of arthropods among nests by bird species (a) and sites (b). Ellipses depict $95 \%$ confidence intervals of data. / Gráficos de escalamiento multidimensional usados para evaluar las diferencias en composición de artrópodos de nidos por especie de ave (a) y sitio (b). Las elipses representan los intervalos de confianza de los datos al $95 \%$. (a)

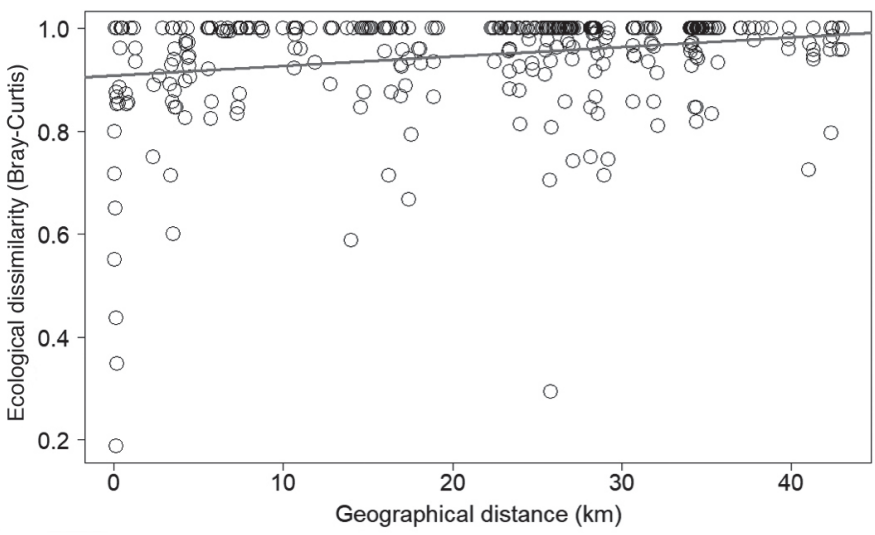

(b)

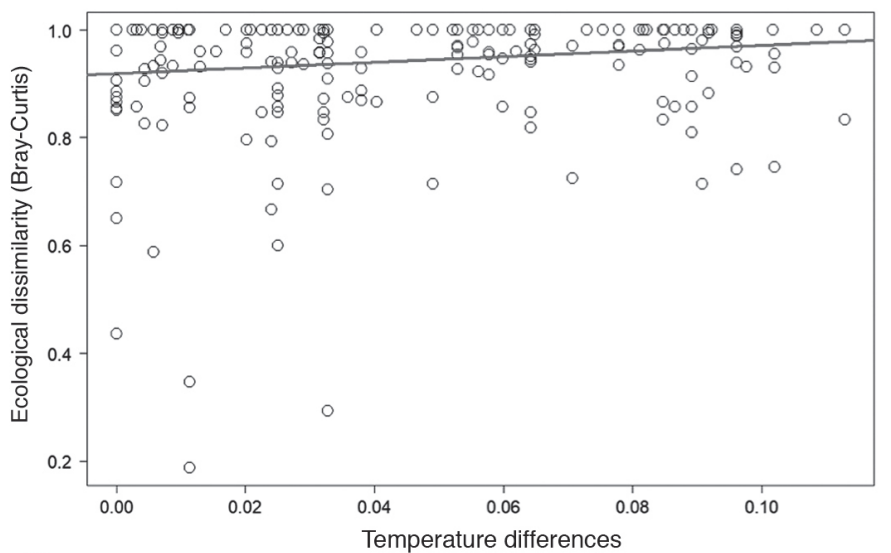

(c)

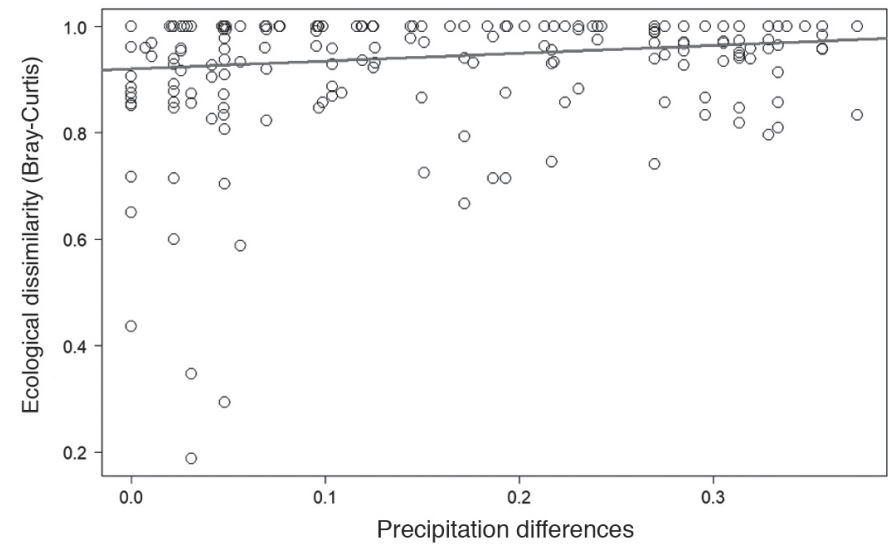

FIGURE 5. Relationship between ecological distance between nests and their geographical distance (a), differences in annual mean temperature (b) and differences in precipitation (c). Ecological distance was estimated using the Bray-Curtis index based on nest arthropod composition. Red lines depict Pearson correlation between distance matrices after a Mantel test. / Relación entre la distancia ecológica entre nidos con la distancia geográfica (a), las diferencias en la temperatura media anual (b) y diferencias en precipitaciones (c). La distancia ecológica fue estimada usando el índice de Bray-Curtis basado en la composición de artrópodos por nido. La línea roja representa el resultado de la correlación de Pearson entre las matrices de distancia después de la prueba de Mantel. 
TABLE 3. Richness of nest arthropods by site along the coastal range of Central Chile. Sites are ordered from north to south. Abbreviation of bird species are Bubo magellanicus (Bmag), Patagioenas araucana (Para), Phytotoma rara (Prar), Pseudasthenes humicola (Phum), Troglodytes aedon (Taed) and Turdus falcklandii (Tfal). / Riqueza de artrópodos en nidos ordenados por sitio a lo largo de la costa de Chile Central. Los sitios fueron ordenados de norte a sur. Las abreviaciones de las especies de ave son Bubo magellanicus (Bmag), Patagioenas araucana (Para), Phytotoma rara (Prar), Pseudasthenes humicola (Phum), Troglodytes aedon (Taed) and Turdus falcklandii (Tfal).

\begin{tabular}{lcccc}
\hline Sites & Sampled nests $(\mathrm{n})$ & Bird species & Observed richness & $\begin{array}{c}\text { Estimated richness } \\
\left(\mathrm{RAR}_{10}, \text { mean }^{\left. \pm \mathrm{Cl}_{95 \%}\right)}\right.\end{array}$ \\
\hline Pichidangui & 4 & Prar, Phum, Tfal & 14 & $29 \pm 15$ \\
Los Molles & 3 & Bmag, Prar, Tfal & 11 & $19 \pm 11$ \\
Zapallar & 1 & Tfal & 3 & - \\
La Canela & 4 & Para, Prar, Taed, Tfal & 16 & $34 \pm 15$ \\
El Mauco & 4 & Phum, Prar & 13 & $24 \pm 12$ \\
El Carmen & 3 & Phum, Tfal & 10 & $24 \pm 14$ \\
Los Pinos & 5 & Phum, Prar & 15 & $24 \pm 11$ \\
Acantilados FSM & 2 & Phum & 2 & - \\
El Yeco & 1 & Prar & 4 & - \\
\hline
\end{tabular}

\section{DISCUSSION}

Our study provides evidence that shed light the drivers that control arthropod diversity within bird nests in a biodiversity hotspot. Bird nests mayactas arthropod refugee as theyprovide resources and present suitable microclimatic conditions. Our analyses performed at two levels, based on taxonomic alpha (richness) and beta (composition) diversity, showed that differences between sites are the main source of variation that explains change in the composition of nest arthropods. Bird species have a less important role in explaining arthropod richness and their assemblage structure, which reinforce the idea that climatic properties may have driven arthropod nest composition. However, our interpretations and conclusions could be limited by the low taxonomic resolution utilized to identify specimens. This situation occurred because many specimens are in early developmental stages within nests (i.e. larval) and it is therefore unfeasible to carry out their proper identification. Approaches using DNA could have been used to determine specimens (such as it was used to identify some birds, see methods) enabling much higher taxonomic resolution, especially for groups that are hard to identify morphologically. However, the large number of arthropod specimens found in nests would raise the costs of our study and render this technique unfeasible. Future studies of arthropod diversity in nests should include this alternative to better support results and conclusions.

All nests in our study contained arthropods, mainly insects and arachnids, which are the main clades widely distributed among bird nests in other studied systems (Woodroffe 1953; Hick 1959; López-Rull \& García 2015). For example, all insect orders described in this study match with those described in Hick's global check-list (Hick 1959). Considering the the low taxonomic resolution achieved in this study (being unable to identify many specimens to the species level) which likely underestimates the species richness of nest arthropods, we consider that our described diversity is relatively high compared to other studies (e.g., Woodroffe 1953). For example, we covered only nine sites and mainly nest of three bird species (each of the other three bird species only had one nest) and obtained 47 taxonomic entities. In contrast, Woodroffe (1953) covered all of England and studied five bird species with a resulting richness of 92 species of nest arthropods. Furthermore, we sampled nests after the egglaying season, when parasites may be absent, which may reduce arthropod occurrence in nests. Another factor that may limit the number of nest arthropods is attributable to plant material used to build nests, since many bird species choose plants with aromatic substances or volatile secondary compounds that act as biocides against arthropods (Lafuma et al. 2001; Quiroga et al. 2012; Dubiec et al. 2013). Plants with secondary compounds that potentially acts as biocide are common along to Central Chile (Muñoz 1992) although information of plant identity used as nesting material by Chilean birds is anecdotic at best, covered partially in some handbooks (Goodall et al. 1957; Hoffmann \& Lazo 2011; Altamirano et al. 2012) and biased to a few cavity-nesting bird species (Honorato et al. 2016; Altamirano et al. 2019). Our 
study did not include information of plant nest composition, which requires specific methods of determination for twigs and plant remains, an objective that is out of the main scope of this study. Differences in vegetation composition among sites may change nest material, in turn impacting the arthropod species within nests. This a stimulating field for future investigations that may integrate different diversity components.

Bird species did not affect arthropod richness nor explained differences in arthropod composition between nests. However, a subtle higher richness was observed in nests of $P$. rara, which had the largest surface area among studied bird nests. Studies have shown that nest mass explains the richness of nest arthropods (e.g., moths, Boyes $\&$ Lewis 2019). In our study, the nest mass did not predict arthropod entity richness. At landscape level, large areas host a higher richness of arthropods (Basset et al. 2012) although the predictive power of landscape area on arthropod diversity could be improved by incorporating microsite areas, such as the nests (Liu et al. 2016). Despite the relatively low number of samples included in this study ( $\mathrm{n}=27$ nests) which could reduce the predictive power of nest dimension on arthropod richness, we detected an important effect of the nest area on arthropod richness. We cannot differentiate this effect by bird species, although our study was performed in a manner to allow the maximum number of natural nests collected as possible, avoiding the use of artificial nests such as nest boxes (e.g., Honorato et al. 2016; Boyes \& Lewis 2019). It is necessary that future studies include a high number of nest samples per species, although this is constrained by nest ubiquity, access to private lands and increase sampling effort with different methodological approaches, i.e., studies may include arthropod traps directly inside the nest to obtain a better representation of arthropod assemblages and use DNA for specimen determination.

Since this is the first report of nest arthropod in the mediterranean-type region of Chile to date, information on the ecological roles of nest arthropods is absent. Some described entities may be related to detrivorous activity as scavengers, i.e., Thysanura and Lepidoptera specimens; as well as coleopterans from Anobiidae and Tenebrionidae (Woodroffe 1953). Other observed arthropods may act as ectoparasites of birds, such as Sarcoptiformes from the Arachnida order (Woodroffe 1953). It is recognized that humidity and temperature conditions are drivers of arthropod composition in nests (Woodroffe 1953). Interestingly, we observed that annual mean temperature and precipitation were the main drivers of nest arthropod composition (beta diversity), although these factors did not explain nest arthropod richness (alpha diversity). Along Central Chile, a strong latitudinal gradient in temperatures and precipitation occur between the northern portion (drier and warmer) and the southern portion (humid and colder). An interesting result is the difference of arthropod composition that changed between northern assemblages, mainly hosting Hemipterans and Hymenopterans, in contrast to the southern portion that mainly hosted species of Collembola, Dermaptera, and Diplopoda orders. In this sense, climatic conditions can not only change arthropod composition between sites, but can also determine ecological interactions (for example, predatorprey relationships) among arthropods within nests (Woodroffe 1953). There is no doubt that more studies are required to characterize ecological interactions between nest fauna.

Our study contributes to understand a mostly unexplored knowledge gap regarding biodiversity, which may have potential consequences for both insect and bird reproductive biology. We are still far away from fully understanding the relation of nest arthropods with other variables, such as plant material of bird nests. Therefore, our knowledge of the natural history of the arthropods of nests is far from complete. Explaining the richness and composition of nest arthropod entities is the first step to gain knowledge about the functional role of insects in nests and the complex relationships that they establish with other community components such as birds, which could, in turn, be related to arthropod dispersal processes.

\section{SUPPORTING INFORMATION}

APPENDIX S1. Data matrix including nest attributes, arthropod composition and abundance per nest. Designation is the name used to identify each specimen when species determination was unfeasible.

APPENDIX S2. PCR primer cocktails used to amplify COI region from the biological remains of bird origin from collected nests. APPENDIX S3. Arthropod species accumulation curves for sampled nests.

\section{ACKNOWLEDGMENTS}

Constanza Schapheer kindly identified coleopterans specimens. Funding by FONDECYT 11150301 to GOC.

\section{REFERENCES}

Aguilera, M.A., Casanueva, M.E. 2005. Arañas chilenas: estado actual del conocimiento y clave para las familias de Araneomorphae. Gayana 69: 201-224.

Alaniz,A.J., Galleguillos, M., Perez-Quezada,J.F. 2016. Assessment 
of quality of input data used to classify ecosystems according to the IUCN Red List methodology: The case of the central Chile hotspot. Biological Conservation 204: 378-385.

Altamirano, T.A., Ibarra, J.T., Hernández, F., Rojas, I., Laker, J., Bonacic, C. 2012. Hábitos de Nidificación de la Aves del Bosque Templado Andino de Chile. Imprenta Maval, Santiago.

Altamirano, T.A., Honorato, M.T., Ibarra, J.T., De la Maza, M., De Zwaan, D.R., Bonacic, C., Martin, K. 2019. Elevation has contrasting effects on avian and mammalian nest traits in the Andean temperate mountains. Austral Ecology 44: 691-701.

Aramburú, R., Calvo, S., Carpintero, D.L., Cicchino, A.C. 2009. Artrópodos presentes en nidos de cotorra Myiopsitta monachus (Aves: Psittacidae). Revista del Museo Argentino de Ciencias Naturales 11: 1-5.

Armesto, J.J., Manuschevich, D., Mora, A., Smith-Ramírez, C., Rozzi, R., Abarzúa, A.M., Marquet, P. 2010. From the Holocene to the Anthropocene: A historical framework for land cover change in southwestern South America in the past 15000 years. Land Use Policy 27: 148-160.

Basset, Y., Cizek, L., Cuénoud, P., Didham, R.K., Guilhaumon, F., Missa, O. et al. 2012. Arthropod diversity in a tropical forest. Science 338: 1481-1484.

Boyes, D.H., Lewis O.T. 2019. Ecology of Lepidoptera associated with bird nests in mid-Wales, UK. Ecological Entomology 44: 1-10.

Clarke, K.R. 1993. Non-parametric multivariate analyses of changes in community structure. Australian Journal of Ecology 18: 117-143.

Colwell, R.K., Chao, A., Gotelli, N.J., Lin, S.Y., Mao, C.X., Chazdon, R.L., Longino, J.T. 2012. Models and estimators linking individual-based and sample-based rarefaction, extrapolation and comparison of assemblages. Journal of Plant Ecology 5: 3-21.

Deeming, D.C., Mainwaring, M.C. 2015. Functional properties of nests. En: Deeming, D.C., Reynolds, S.J. (Eds) Nests, eggs and incubation: 29-49. Oxford University Press, Oxford.

Di lorio, O., Turienzo, P. 2009. Insects found in birds' nests from the Neotropical Region (except Argentina) and immigrants in the Nearctic Region. Zootaxa 2187: 1-144.

Di lorio, O., Turienzo, P. 2016. The family Cavognathidae (Coleoptera: Cucujoidea) in Argentina and adjacent countries. Zootaxa 4092: 90-106.

Dubiec, A., Gózdz, I., Mazgajski, T.D. 2013. Green plant material in avian nests. Avian Biological Research 6: 133-146.

Esler, K.J., Jacobsen, A.L., Pratt, R.B. 2018. The Biology of Mediterranean-Type Ecosystems. Oxford University Press, Oxford.
Fecchio, A., Svensson-Coelho, M., Bell, J., Ellis, V.A., Medeiros, M.C., et al. 2017. Host associations and turnover of haemosporidian parasites in manakins (Aves: Pipridae). Parasitology 144: 984-993.

Goodall, J.D., Johnson, A.W., Philippi, R.A. 1957. Las aves de Chile: su conocimiento y sus costumbres. Tomo I y Suplemento. Platt Establecimientos Gráficos S.A., Argentina.

Grismado, C.J., Ramírez, M.J., Izquierdo, M.A. 2014. Araneae: Taxonomía, Diversidad y clave de identificación de familias de la Argentina. Biodiversidad de Artrópodos Argentinos 3: 55-94.

Harte, J., Smith, A.B., Storch, D. 2009. Biodiversity scales from plots to biomes with a universal species-area curve. Ecology Letters 12: 789-797.

Hebert, P.D.N., Cywinska, A., Ball, S.L., deWaard, J.R. 2003. Biological identifications through DNA barcodes. Proceedings of the Royal Society B-Biological Sciences 270: 313-321.

Heenan C.B., Seymour, R.S. 2011. Structural support, not insulation, is the primary driver for avian cup-shaped nest design. Proceedings of the Royal Society B-Biological Sciences 278: 2924-229.

Hicks, E.A. 1959. Check-list and bibliography on the occurrence of insects in bird nests. lowa State College Press, USA.

Hijmans, R.J., Cameron, S.E., Parra, J.L., Jones, P.G., Jarvis, A. 2005. Very high resolution interpolated climate surfaces for global land areas. International Journal of Climatology 25: 1965-1978.

Hoffmann, A., Lazo, I. 2011. Aves de Chile. Un libro también para niños. Andros Impresores, Santiago.

Honorato, M.T., Altamirano, T.A., Ibarra, J.T., De la Maza, M., Bonacic, C., Martin, K. 2016. Composición y preferencia de materiales en nidos de vertebrados nidificadores de cavidades en el bosque templado andino de Chile. Bosque 37: 485-492.

Hsieh, T.C., Ma, K.H., Chao, A. 2016. iNEXT: An R package for rarefaction and extrapolation of species diversity (Hill numbers). Methods in Ecology and Evolution 7: 14511456.

Ivanova, N.V., Zemlak, T.S., Hanner, R.H., Hebert, P.D.N. 2007. Universal primer cocktails for fish DNA barcoding. Molecular Ecology Notes 7: 544-548.

Jetz, W., Thomas, G.H., Joy, J.B., Hartmann, K., Mooers, A.O. 2012. The global diversity of birds in space and time. Nature 491: 444-448.

Judd, W.W. 1962. Insects and other invertebrates from nests of the Cardinal, Richmondena cardinalis (L.), at London, Ontario. Canadian Entomologist 94: 92-95.

Kembel, S.W., Cowan, P.D., Helmus, M.R., Cornwell, W.K., Morlon, H., Ackerly, D.D., Blomberg, S.P., Webb, C.O. 
2010. Picante: R tools for integrating phylogenies and ecology. Bioinformatics 26: 1463-1464.

Lafuma, L., Lambrechts, M.M., Raymond, M. 2001. Aromatic plants in bird nests as a protection against bloodsucking flying insects? Behavioural Process 56: 113-120.

Lambrechts, M.M., Schatz, B., Bourgault, P. 2008. Interactions between ants and breeding Paridae in two distinct Corsican oak habitats. Folia Zoologica 57: 264-268.

Liu, R., Pen-Mouratov, S., Steinberger, Y. 2016. Shrub cover expressed as an "arthropod island" in xeric environments. Arthropod-Plant Interactions 10: 393-402.

López-Rull, I., García, C.M. 2015. Control of invertebrate occupants of nests. En: Deeming, D.C., Reynolds, S.J. (Eds) Nests, eggs and incubation: 82-96. Oxford University Press, Oxford.

Luebert, F., Pliscoff, P. 2006. Sinópsis Bioclimática y Vegetacional de Chile. Ed. Universitaria, Santiago.

Lundqvist, L. 1988. Reproductive strategies of ectoparasites on small mammals. Canadian Journal of Zoology 66: 774781.

Mainwaring, M.C., Hartley, I.R., Lambrechts, M.M., Deeming D.C. 2014. The design and function of birds' nests. Ecology and Evolution 4: 3909-3928.

Mantel, N. 1967. The detection of disease clustering and a generalized regression approach. Cancer Research 27: 209-220.

Miquel, S.E., Turienzo, P., Di lorio, O.R. 2015. Gastropod species found in birds' nests from Argentina. Revista del Museo Argentino de Ciencias Naturales 17: 87-96.

Myers, N., Mittermeier, R.A., Mittermeier, C.G., da Fonseca, G.A.B., Kent, J. 2000. Biodiversity hotspots for conservation priorities. Nature 403: 853-858.

Muñoz, O. 1992. Química de la Flora de Chile. Departamento Técnico de Investigación, Universidad de Chile, Santiago.

Peña, L.E. 2006. Introducción al estudio de los Insectos de Chile. Editorial Universitaria, Santiago.

Poulin, R. 2011. Evolutionary Ecology of Parasites. Princeton University Press, New Jersey.

Poulin, R., Krasnov, B.R., Mouillot, D. 2011. Host specificity in phylogenetic and geographic space. Trends in Parasitology
27: 355-361.

Quiroga, M.A., Reboreda, J.C., Beltzer, A.H. 2012. Host use by Philornis sp. in a passerine community in central Argentina. Revista Mexicana de Biodiversidad 83: 110-116.

R Core Team. 2019. R: A Language and Environment for Statistical Computing. R Foundation for Statistical Computing, Vienna. URL: https://www.R-project.org.

Rataud, A., Dupraz, M., Toty, C., Blanchon, T., Vittecoq, M., Choquet, R., McCoy, K.D. 2019. Evaluating functional dispersal and its eco-epidemiological implications in a nest ectoparasite. Peer Community in Ecology. URL: https://dx.doi.org/10.24072/pci.ecology.100013 Acceso: Abril 25, 2019.

Ratnasingham, S., Hebert, P.D.N. 2007. BOLD: The Barcode of Life Data System, www.barcodinglife.org. Molecular Ecology Notes 7: 355-364.

Rezende, E.L., Lavabre, J.E., Guimaraes, Jr., P.R., Jordano, P., Bascompte, J. 2007. Non-random coextinctions in phylogenetically structured mutualistic networks. Nature 448: 925-928.

Saiz, F., Solervicens, J., Ojeda, P. 1989. Coleópteros del Parque Nacional La Campana y Chile Central. Ediciones Universidad Católica de Valparaíso, Chile.

Slipinski, A., Tomaszewska, W. 2010. Revision of the family Cavognathidae (Coleoptera: Cucujoidea). Austral Entomology 49: 256-267.

Solervicens, J. 2014. Coleópteros de la Reserva Nacional Río Clarillo. Chile Central: Taxonomía, Biología y Biogeografía. Corporación Nacional Forestal, Gerencia de Áreas Silvestres Protegidas, Santiago, Chile.

Tajovský, K., Mock, A., Krumpál, M. 2001. Millipedes (Diplopoda) in birds' nests. European Journal of Soil Biology 37: 321323.

Winkler, D.W., Sheldon, F.H. 1993. Evolution of nest construction in swallows (Hirundinidae): A molecular phylogenetic perspective. Proceedings of the National Academy of Sciences USA 90: 5705-5707.

Woodroffe, G.E. 1953. An ecological study of the insects and mites in the nests of certain birds in Britain. Bulletin of Entomological Research 44: 739-772.

Received: 13.09.2019

Accepted: 23.01.2020 